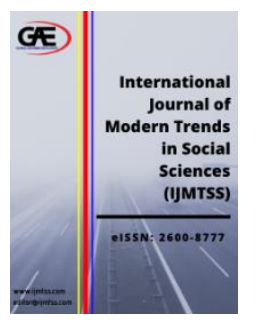

\author{
International Journal of Modern Trends in \\ Social Sciences (IJMTSS) \\ Journal Website: http://ijmtss.com/ \\ eISSN: 2600-8777
}

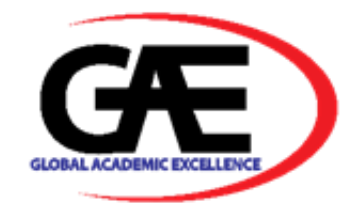

\title{
LEARNING STATISTICS COURSE USING COMPUTER_AIDED SOFTWARE: A CASE STUDY AMONG FURNITURE TECHNOLOGY STUDENTS
}

\author{
Aszila Asmat $^{1 *}$, Syafiza Saila Samsudin ${ }^{2}$, Sharifah Norhuda Syed Wahid ${ }^{3}$ \\ 1 Faculty of Computer and Mathematical Sciences, Universiti Teknologi MARA Cawangan Pahang, Malaysia \\ Email: aszila@uitm.edu.my \\ 2 Faculty of Computer and Mathematical Sciences, Universiti Teknologi MARA Cawangan Pahang, Malaysia \\ Email: syafi915@uitm.edu.my \\ 3 Faculty of Computer and Mathematical Sciences, Universiti Teknologi MARA Cawangan Pahang, Malaysia \\ Email: sha_huda@uitm.edu.my \\ * Corresponding Author
}

\section{Article Info:}

\section{Article history:}

Received date: 30.01 .2020

Revised date: 17.02.2020

Accepted date: 03.03.2020

Published date: 15.03 .2020

\section{To cite this document:}

Asmat, A., Samsudin, S. S., Wahid, S. N. S. (2020). Learning Statistics Course using Computer-aided Software: A Case Study among Furniture Technology Students. International Journal of Modern Trends in Social Sciences, 3 (11), 99106.

DOI: 10.35631/IJMTSS. 311008 .

\begin{abstract}
:
Computer-aided software is one of the most promising innovations to improve the teaching and learning process. With the integration of modern information and communication technologies, various computer-aided software has been developed and used to facilitate students in various courses. This study only focusing on learning statistics courses with the use of Minitab software as a computer-aided software. Thus, to measure the effectiveness of learning statistics courses using the computer-aided software, 26 students who enrolled in statistics courses were selected. As a result, it is found that there is a significant improvement in students' scores when Minitab software was used in the course. The average of score also showed improvement by more than 14 percent compared to the traditional approach. The positive impact of students' performance indicated that computer-aided learning is more applicable to be implemented in many different courses, not only limited to statistics.
\end{abstract}

Keywords:

Computer-Aided Software, Minitab, Statistics

\section{Introduction}

Cobb, George and Moore (1997) had defined statistics is a "methodological discipline study of a coherent set of ideas and tools for dealing with data. The focus on variability naturally gives statistics a particular content that sets it apart from mathematics itself and from other mathematical sciences, but there is more than just content that distinguishes statistical thinking 
and mathematical thinking, because data are not just number, they are number with a context". The definition by Cob et al. (1997) is consistent to the Brook (2010), who stated that statistics is the study of the collection, analysis, interpretation, presentation, and organization of data which dealing with all aspects of data including the design of surveys and also the experiments.

Statistics becomes a very useful course due to the knowledge and skill gathered can be applied in different disciplines including social sciences and technology whereby Maat and Rosli (2016) stated that this course essential in many professional fields. In addition, statistics also becomes among the most important course in higher education level due to the higher demand from government and private sectors. Lehman and Nisbett (1990) and supported by VanderStoep and Shaughneesy (1997) agreed that statistical knowledge increases critical reasoning and conditional logic. For this reason, statistics has started to be introduced as a compulsory subject at higher learning institution, so that majority of the programs offer this course in their curriculum structure.

According to Aszila, Suriyati and Sharifah Norhuda (2015) in their study found that many perceptions were given to statistics course by students at higher learning institution such as it is considered as a killer course, difficult to understand and hard to score. These negative perceptions occurred based on the way statistics knowledge and skills were delivered that caused statistics anxiety. Statistics anxiety is defined as "feelings of anxiety encountered when taking a statistics course or doing statistical analyses" (Cruise, Cash, \& Bolton, 1985). Siew, McCartney and Vitevitch (2019) in their study suggested that to change students' perception that strong mathematical ability is a perquisite to have excellence performance in statistics. Therefore, this study targeted different technique to identify the students' performance in statistics course by using computer software rather than their mathematical ability in learning introductory statistics course at higher learning institution.

Consequently, the aim of this study is to measure the effectiveness of computer-aided learning as teaching method of statistics course. The statistical software used in learning process conducted in lab session will provides instructors with external quality elements. This paper discusses the early phase of the teaching and learning process using traditional method followed by statistical software method.

\section{Literature Review}

In general, the teachers or instructors are trying to teach with their own understanding and beliefs. Teaching method refers to the general principles, pedagogy and management strategies used for conducting learning process. The used of teaching method depends on the different factors; educational philosophy, classroom demographic, subject or course area and may influenced by school mission itself. As stated by Mahmud (2001), a suitable teaching method used will attract students to take part in the learning session because being attracted to learn is very important factor to evaluate the students' acceptance toward learning process.

Different methods used in teaching and learning process in calculation course including mathematics and statistics. According to Bergeson (2000), the students would try to learn especially in calculation subject with their maturity, intellectual ability, preferred learning styles, attitude and social adjustment. In addition, Greer (n.d.) suggested that a concept mapping learning technique can be used in order to improve the quality of learning mathematics and blended learning also will reflect teaching learning to be better ( $\mathrm{Ng}, 2005)$. After a decade, Ozofor (2015) found that secondary school students that used computer aided performed better in solving mathematics problem and he also suggested that the government 
should provide computer literacy program for secondary schools mathematics teachers. Furthermore, Aszila et al. (2015) revealed that there was significant difference in students' performance after they successfully conducted the probability workshop whereby students' performance in probability topic are better after they attended the workshop.

Nowadays, teaching and learning process are facing new era of education transformation. One of the basic requirements for education in the future is to prepare the students to participate in the knowledge that related to social and economic development (Ministry of Education, 2015). Educational institutions are being forced to find better pedagogical methods to cope with these new challenges. Due to this process of development, it is expected that computers could play an important role in restructuring teaching and learning processes to be better prepared for future challenges. Computer-aided learning is one of the most promising invention to improve teaching and learning process that has integrated both modern information and communication technology. This tool becomes one of the most innovations in educational process that can be an interactive method to be used in teaching and learning process, not only limited to qualitative course, but also quantitative course such as statistics.

Therefore, the evaluation of teaching method should be implemented not only limited to traditional method but using computer-aided learning method. According to Nisanci (2000), also Furner and Daigle (2004), the effectiveness of educational evaluation is the primary area with which developers of learning software must concern so that the learning process will be more successful. Hoon, Chong and Azilah (2010) mentioned that computer assisted cooperative learning and computer assisted mastery learning enables students to provide them to achieve good result in mathematics. In addition, Azidah, Fatariah and Ahmad (2012) had conducted a study among students in learning drawing using software as a learning support tools found that the students had an excellent improvement in drawing skills. Erlina and Zakaria (2014) also revealed that the students' performance in mathematics improved after they used Geogebra software to teach mathematics. Geogebra software is a dynamic mathematics software that brings together geometry, algebra, spreadsheets, graphing, statistics and also calculus. Not limited to calculation subject, Raafat, Nabil, Taleb et al. (2014) also used the computer-aided software to help students increasing the understanding level of chemical engineering problem and this method was proven effective when the understanding level among students towards chemical engineering problem become better.

As stated earlier, the objective of this study is to measure the effectiveness of computer-aided learning as interactive and powerful tool to teach statistics course, not focused only on traditional method. Cobb et al. (1997) and Brook (2010) stated that one of the steps in statistics is data analyzing. Statistics itself can be analyzed using the statistical software such as SPSS, Minitab, SAS, S-Plus and R. One of the most popular statistical software among science and technology field is Minitab. Minitab is a statistics package developed by Barbara, Ryan, Thomas et al. (1972) at the Pennsylvania State University. This software is distributed by Minitab Inc, a privately owned company headquartered in State College, Pennsylvania (Meyer \& David, 2004).

\section{Methodology}

The sample comprised all 26 students of Bachelor in Furniture Technology from one of the public universities in Malaysia. Majority were female (68\%) and the rest were male (32\%). The students were enrolled a statistics course namely Statistics for Sciences and Engineering. The course covered the basic and intermediate methods of data analysis including probability distribution, correlation, regression, hypothesis testing and analysis of variance. Students also 
will be able to interpret the computer output from the Minitab software. For this reason, students need to know how to solve the given questions especially correlation, regression, hypothesis testing and analysis of variance topics using two different methods; calculate manually or based on computer output. Among these topics, majority of students are facing problem in hypothesis testing topic when they have been tested in short quiz.

Two different sets of tests were developed in order to measure students' performance in statistics course. The first test, Test A, comprised of hypothesis testing questions that need students to calculate manually on every solution in order to finally come out with the results and conclusion. On the other hand, Test B had applied Minitab output in the hypothesis testing question to achieve the same goals. In order to measure the effectiveness of computer-aided learning as a teaching method, scores for both tests were recorded. Students were also asked to answer a self-developed questionnaire which contain 10-items, including a set of demographic questions. Responses for the questionnaire were based on Likert scale that ranged from 1= Strongly Agree to $5=$ Strongly Disagree. All students participated on a voluntary basis by answering the questionnaire. The collected data then will be analyzed using descriptive statistics and paired sample t-test. For paired sample t-test, the null hypothesis was set to identify whether there is no significant improvement in students' score when computer-aided software was used as teaching method in Statistics course. The Statistical Procedures for Social Sciences (SPSS) was used to analyze the data.

\section{Finding and Discussion}

Total of 26 students from Bachelor in Furniture Technology were involved in this study. From all participated students, $65.3 \%$ preferred the use of computer-aided software in learning statistics course, and the other $34.7 \%$ were disagree. Table 1 showed that $56.8 \%$ of the students agreed that statistics is an easy course if Minitab is used in the data analysis part, and $46.2 \%$ were unsure. Result also revealed that $61.5 \%$ students enjoyed learning statistics with the use of Minitab.

Table 1: Students' Acceptance Towards the Use of Minitab in Statistics

\begin{tabular}{lccccc}
\hline Statement & $\begin{array}{c}\text { Strongly } \\
\text { Disagree }\end{array}$ & Disagree & Neutral & Agree & $\begin{array}{l}\text { Strongly } \\
\text { Agree }\end{array}$ \\
\hline $\begin{array}{l}\text { Statistics is an easy course if using } \\
\text { Minitab in the data analysis }\end{array}$ & 0.0 & 0.0 & 46.2 & 42.3 & 11.5 \\
\hline I enjoy learning statistics using Minitab & 0.0 & 3.8 & 34.6 & 50 & 11.5 \\
\hline
\end{tabular}

According to the result showed in Table 2, it is found that $57.7 \%$ of the students agreed that they would understand better when learning statistics with the use of Minitab, but $3.8 \%$ were disagree. Majority of the students also agreed that Minitab as the computer-aided software were more applicable in data analysis part and helped them to understand the concepts in statistics better.

Table 2: Students' Opinion Towards the Use of Minitab in Statistics

\begin{tabular}{lccccc}
\hline Statement & $\begin{array}{c}\text { Strongly } \\
\text { Disagree }\end{array}$ & Disagree & Neutral & Agree & $\begin{array}{c}\text { Strongly } \\
\text { Agree }\end{array}$ \\
\hline $\begin{array}{l}\text { I will understand better when learning } \\
\text { statistics with the use of Minitab }\end{array}$ & 0.0 & 3.8 & 38.5 & 46.2 & 11.5 \\
\hline
\end{tabular}




\begin{tabular}{llllll}
\hline $\begin{array}{l}\text { I think statistics will be more } \\
\text { applicable with the use of Minitab }\end{array}$ & 0.0 & 3.8 & 30.8 & 53.8 & 11.5 \\
\hline $\begin{array}{l}\text { I think I will explain the concepts in } \\
\text { statistics better with the use of Minitab }\end{array}$ & 0.0 & 7.7 & 26.9 & 57.7 & 7.7 \\
\hline
\end{tabular}

The analysis continued with the paired sample t-test for Test A and Test B as shown in Table 3 to measure the effectiveness of computer-aided software as a teaching tools in learning statistics course. Test A referred to test that needs students to calculate manually each of the solutions and come out with their finding and conclusion, meanwhile Test B referred to test with provided output from Minitab software in order to describe finding and conclusion. The results revealed that the $p$-value of Test A and Test B scores data is 0.000 (less than 0.05) which indicated there were statistically differences between mean score obtained for Test A and Test B. Since the null hypothesis is rejected, it can be concluded that there is strong evidence $(\mathrm{t}=$ 8.089 , p-value $=0.000$ ) that the students' score has improved when computer-aided learning was used as teaching methods.

Table 3: Paired Sample t-Test

\begin{tabular}{cccc}
\hline Statistic & T & Degree of freedom & $\boldsymbol{p}$-value \\
\hline Test A-Test B & 8.089 & 25 & 0.000 \\
\hline
\end{tabular}

According to Table 4, the mean scores for Test $\mathrm{A}$ and Test $\mathrm{B}$ are $76.73 \%$ and $91.15 \%$ respectively. The finding indicates that the test using output from Minitab software had improved students' score in statistics subject on average by approximately 14 points. The results obtained have been supported by Azidah et al. (2012) who stated that there is an excellent improvement in students' achievement in learning engineering drawing after using software as a learning support tool. The other study conducted by Raafat et al. (2014) also found that computer-aided software helped students in enhancing their understanding of chemical engineering problems.

Table 4: Paired Sample Statistics

\begin{tabular}{ccccc}
\hline Test & Mean & $\begin{array}{c}\text { No of } \\
\text { students }\end{array}$ & $\begin{array}{c}\text { Standard } \\
\text { deviation }\end{array}$ & $\begin{array}{c}\text { Standard error } \\
\text { of the mean }\end{array}$ \\
\hline Test A & 76.73 & 26 & 10.67 & 2.09 \\
Test B & 91.15 & 26 & 6.05 & 1.19 \\
\hline
\end{tabular}

The analysis continued to identify the students' opinion towards the use of computer-aided software in learning statistics course. In order to achieve the objective, the correlation analysis was run between the opinion towards the use of computer-aided software (y) and the three independent variables which are attitude $\left(\mathrm{X}_{1}\right)$, ability to adapt computer-aided software $\left(\mathrm{X}_{2}\right)$ and ability to change $\left(\mathrm{X}_{3}\right)$. The result was shown in Table 4 . Based on the value of Pearson Correlation, it showed there are a strong positive relationship between opinion towards the use computer-aided software and attitude $(r=0.755)$ and opinion towards the use of computeraided software and ability to adapt computer-aided software $(r=0.539)$. However, there is a moderate strong positive relationship between opinion towards the use of computer-aided software and ability to adapt changes $(r=0.444)$. 
Table 4: Correlation Analysis

\begin{tabular}{lccc}
\hline & $\boldsymbol{X}_{\mathbf{1}}$ & $\boldsymbol{X}_{\mathbf{2}}$ & $\boldsymbol{X}_{\mathbf{3}}$ \\
\hline $\begin{array}{l}\text { Pearson } \\
\text { Correlation }\end{array}$ & 0.755 & 0.539 & 0.444 \\
\hline p-value & 0.000 & 0.005 & 0.023 \\
\hline
\end{tabular}

Since all the p-value is less than 0.05 suggested the regression analysis to be carried out. In general, the regression model is written as

$$
y=\beta_{0}+\beta_{1} X_{1}+\beta_{2} X_{2}+\beta_{3} X_{3}+\varepsilon_{i}
$$

Where $\beta_{0}$ is the y-intercept, $\beta_{1}, \beta_{2}$ and $\beta_{3}$ are the regression coefficient and $\varepsilon_{i}$ is the random error? Results from the analysis of variance as shown in Table 5 revealed that the model is significant $(F=28.025, p-$ value $<0.05)$. This suggests at least one of the independent variables is significant to opinion towards the use of computer-aided software in learning statistics course. The value of R-square for the model is 0.793 revealed that $79.3 \%$ of the total variation in opinion towards the use of computer-aided software can be explained by the three independent variables.

Table 5: Analysis of Variance

\begin{tabular}{cccccc}
\hline $\begin{array}{c}\text { Source of } \\
\text { variation }\end{array}$ & $\begin{array}{c}\text { Sum of } \\
\text { Squares }\end{array}$ & $\begin{array}{c}\text { Degree of } \\
\text { freedom }\end{array}$ & $\begin{array}{c}\text { Mean } \\
\text { Square }\end{array}$ & F & p-value \\
\hline Regression & 7.438 & 3 & 2.479 & 28.025 & 0.000 \\
Error & 1.946 & 22 & 0.088 & & \\
Total & 9.385 & 25 & & & \\
\hline
\end{tabular}

Based on results in Table 6, it shows that all the three independent variables are significant to the opinion towards the use of computer-aided software since all the p-values are less than 0.05. The results indicated students with positive attitude tends to have positive opinion towards the use of computer-aided software in learning statistics course. Students who able to adapt computer-aided software used in learning courses as well as able to adapt changes showed positive opinion towards the use of computer-aided software in learning statistics course. The results in Table 6 also revealed the most important and significant independent variable is ability to adapt changes $(\beta=0.596, p-$ value $<0.05)$, followed by attitude $(\beta=0.373, p-$ value $<0.05)$.

Table 6: Regression Analysis

\begin{tabular}{cccccc}
\hline & $\begin{array}{c}\text { Unstandardized } \\
\text { Beta }\end{array}$ & $\begin{array}{c}\text { Standardized } \\
\text { Beta }\end{array}$ & $\mathbf{t}$ & Sig. & VIF \\
\hline Constant & -0.242 & & -0.506 & 0.618 & \\
$X_{1}$ & 0.316 & 0.373 & 3.812 & 0.001 & 1.016 \\
$X_{2}$ & 0.313 & 0.329 & 3.171 & 0.004 & 1.141 \\
$X_{3}$ & 0.490 & 0.596 & 5.708 & 0.000 & 1.157 \\
\hline
\end{tabular}

In addition, results in Table 6 revealed there is no multicollinearity problem exist between independent variables since all VIF values are less than 10. Therefore, the estimated regression model that consist of the three independent variables is written as 


\section{Conclusion}

This study was conducted to measure the effectiveness of computer-aided learning as a teaching method in statistics course. The statistical software used in learning process conducted in lab session had provided instructors with external quality elements. The finding indicates that the test result using Minitab software improved students' score in statistics subject. The score on average increased by approximately 14 percent. It has proven that using software will help students to increase their performance. For further research, this method could be expanded to other campuses and courses for more representative result. For early exposure, statistical software for statistics course should be introduced for diploma level.

\section{References}

Aszila A, Suriyati U, Sharifah Norhuda SW. (2015). Probability Workshop to Be Better in Probability Topic. Journal of Applied Physic, 1643 (120).

Azidah AZ, Fatariah Z, Ahmad, NO. (2012). Effectiveness of AutoCAD 3D Software as a Learning Support Tool. International Journal of Engineering and Technology, 7(2).

Bergeson T. (2000). Teaching and learning mathematics using research to shift from the "yesterday" mind to the "tomorrow" mind. Retrieved October 1, 2019, from http://www.k12.wa.us/research/pubdocs/pdf/MathBook.pdf

Brook, Quentin (2010). Lean Six Sigma and Minitab: The Complete Toolbox Guide for All Lean Six Sigma Practitioners (3rd ed.). United Kingdom: OPEX Resources Ltd. ISBN 978-0-9546813-6-4

Cobb, George W. and Moore (November 1997). "Mathematics, Statistics, and Teaching". The American Mathematical Monthly104 (9): 801-823.

Cruise, RJ, Cash, RW and Bolton, DL. (1985). Development and validation of an instrument to measure statistical anxiety. In Proceedings of the American Statistical Association section on statistics education (Vol. 4, pp. 92-97). Alexandria, VA: American Statistical Association.

Erlina, A. and Zakaria, E. (2014). Kesan penggunaan perisian geogebra ke atas keupayaan penyelesaian masalah dan pencapaian matematik pelajar. Jurnal Pendidikan Matematik, 2 (1), 51-64.

Furner JM and Daigle D (2004). The Educational Software/Websites Effectiveness Survey.International Journal of Instructional Media (Int J Instr Media), 31(1): 61-77.

Greer G. (n.d.). The effective of concept maps in assessment and learning in Mathematics Education. $\quad$ Retrieved October 1, 2019, from http://napaneedss.limestone.on.ca/greer/teachers/cm/cmappaper.pdf

Hoon TS, Chong TS and Ngah NA (2010). Effect of an Interactive Courseware in the Learning of Matrices. Educational Technology \& Society, 13 (1), 121-132.

Lehman DR and Nisbett RE (1990). A longitudinal study of the effects of undergraduate training on reasoning. Developmental Psychology, 26, 952-960.

Maat SM and Rosli MK (2016). The Rasch model analysis for statistical anxiety rating scale (STARS). Creative Education, 7, 2820-2828.

Mahmud Yahya, (2001). Keupayaan dan Kemahiran Berfikir Dalam Penyelesaian Matematik Tambahan. Tesis Sarjana Pendidikan, Universiti Kebangsaan Malaysia.

Meyer, Ruth K, David D and Krueger (2004). A Minitab Guide to Statistics (3rd ed.). Upper Saddle River, NJ: Prentice-Hall Publishing. ISBN 978-0-13-149272-1.

$\mathrm{Ng}$ SF (2005). Teachers as learners, teachers as reflective practitioners: A model for professional development. In Parmjit Singh \& Lim Chap Sam (Eds.), Improving teaching and learning of mathematics from research to practice (pp. 1-26). Shah Alam: UPENA. 
Nisanci M (2000). Instructional software evaluation Criteria Used by the Teachers: Implications from Theory to Practice. In: Society forInformation Technology \& Teacher Education International Conference: Proceedings of SITE 2000 (11th, San Diego, California, February 8-12, 2000), 1-3.

Ozofor NM (2015). Effect of two modes of computer aided instruction on students' achievement and interest in statistic and probability. International Journal of Education and Research. 3(1):89-102.

Raafat A, Nabil AJ, Taleb HI and Ghaleb AH (2014) Incorpoating Computer-aided Software in the undergraduate Chemical Engineering Core Courses. Chemical Engineering Education, 48(1).

Siew CS, McCartney MJ and Vitevitch MS (2019). Using network science to understand statistics anxiety among college students. Scholarship of Teaching and Learning in Psychology, 5(1), 75-89.

VanderStoep SW and Shaughnessy JJ (1997). Taking a course in research methods improves reasoning about real-life events. Teaching of Psychology, 24, 122-124. 